\title{
Tetrel Bonding Interactions Involving Carbon at Work: Recent Advances in Crystal Engineering and Catalysis
}

\author{
Antonio Frontera \\ Departament de Química, Universitat de les Illes Balears, Crta. de Valldemossa km 7.5, \\ 07122 Palma de Mallorca (Baleares), Spain; toni.frontera@uib.es
}

Received: 2 September 2020; Accepted: 24 September 2020; Published: 25 September 2020

\begin{abstract}
The $\sigma$ - and $\pi$-hole interactions are used to define attractive forces involving elements of groups 12-18 of the periodic table acting as Lewis acids and any electron rich site (Lewis base, anion, and $\pi$-system). When the electrophilic atom belongs to group 14, the resulting interaction is termed a tetrel bond. In the first part of this feature paper, tetrel bonds formed in crystalline solids involving $\mathrm{sp}^{3}$-hybridized carbon atom are described and discussed by using selected structures retrieved from the Cambridge Structural Database. The interaction is characterized by a strong directionality (close to linearity) due to the small size of the $\sigma$-hole in the C-atom opposite the covalently bonded electron withdrawing group. The second part describes the utilization of two allotropic forms of carbon ( $\mathrm{C}_{60}$ and carbon nanotubes) as supramolecular catalysts based on anion $-\pi$ interactions ( $\pi$-hole tetrel bonding). This part emphasizes that the $\pi$-hole, which is considerably more accessible by nucleophiles than the $\sigma$-hole, can be conveniently used in supramolecular catalysis.
\end{abstract}

Keywords: tetrel bonding; crystal engineering; catalysis; $\sigma$-hole; $\pi$-hole

\section{Introduction}

Many chemical transformations, properties of materials, and biological processes are directed by noncovalent interactions [1,2]. They also play a prominent role in self-assembly and formation of supramolecular entities [3-5], design of drugs [6], inhibitors [7], and even optoelectronic devices [8]. The most studied and used noncovalent interactions in supramolecular chemistry and crystal engineering are the ubiquitous hydrogen bond (HB) [9] and $\pi-\pi$ stacking [10] interactions. However, other interactions have stepped out of the shadow of $\mathrm{HB}$ and have started to shine. These can be divided into the following two main groups: (i) ion- $\pi$ interactions [11,12] and (ii) the emerging $\sigma$ - and $\pi$-hole interactions [13,14], which involve elements of groups 12-18 of the periodic table [15-22].

The location of $\sigma$ - and $\pi$-holes (regions of positive electrostatic potential at the surface of atoms or group of atoms) is directly associated with the position and number of the covalent bonds that the atoms form. The number of covalent bonds and the presence/absence of additional lone pairs are related to the group of the periodic table that the atom belongs to, and thus this allows for a convenient and periodic classification of interactions. For instance, tetrel, pnicogen, chalcogen, and halogen atoms (group 14, 15, 16, and 17, respectively) usually form four, three, two, and one covalent bonds, respectively, and they concomitantly present four, three, two, and one $\sigma$-holes opposite them. These depleted areas of electron density can function as electrophilic sites and attractively interact with electron rich atoms or $\pi$-systems. Taking the hydrogen bond (HB) as a model, the names used to designate $\sigma$ - and $\pi$-hole interactions refer to the group of the periodic table where the electrophilic site belongs. Resnati's group proposed this methodology, in 2014, to term the interactions between electrophiles and nucleophiles [20,21] that has been adopted [23] by most of the scientific community. Actually, the terms halogen bond [24] and chalcogen bond [25] are now recommended by IUPAC. The terms triel bond [26], tetrel bond [27,28], pnictogen bond [29,30], and noble gas bond (NgB) [17-19] 
are consistently used to describe attractive noncovalent interactions where atoms that belong to groups $13,14,15$, and 18, respectively, of the periodic table, act as Lewis acids (see Figure 1).

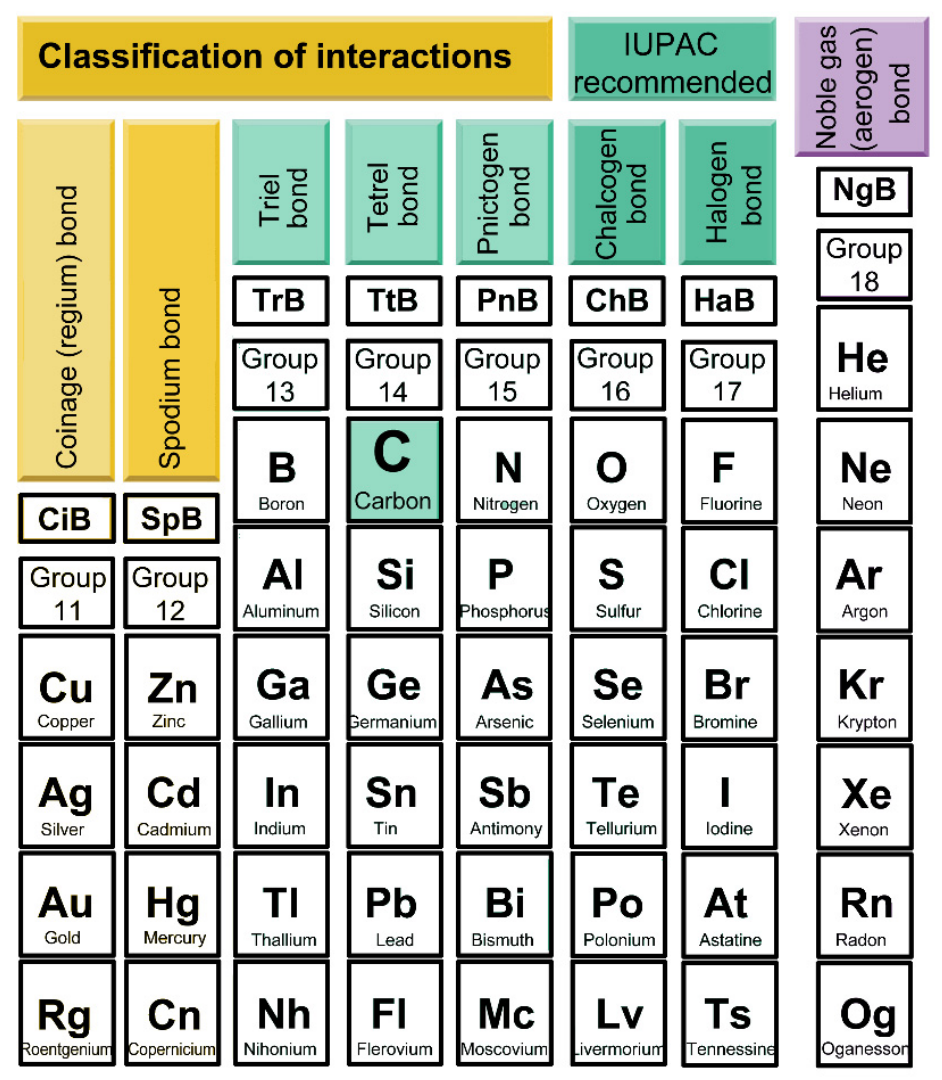

Figure 1. Names used to refer to the interactions where groups 11 to 18 act as Lewis acids.

It is well known that some elements of d block can work as the electrophilic site in adducts with donors of electron density [31-33]. This convention for naming interactions can be easily extended to the $\mathrm{d}$ block elements $[16,20]$. In fact, the term coinage metal bond (CiB) $[16,34]$ is now used for interactions involving elements of group 11 and spodium bond (SpB) for those of group 12 [15,16].

This feature paper is divided into two main topics. The first topic describes tetrel bonding formed in crystalline solids by electrophilic $\mathrm{sp}^{3}$-hybridized carbon atoms to illustrate the importance of tetrel bonds involving the lightest tetrel atom in crystal engineering. To do so, structures from the Cambridge Structural Database (CSD) [35] in which tetrel bonds (TtBs) are important to understand their crystal packing, have been selected and discussed. This analysis is convenient to investigate the geometric features of such contacts and to compare them with computational studies [36-40] on TtBs involving $\mathrm{sp}^{3}$-hybridized carbon atoms. The second topic highlights the utilization of anion- $\pi$ or $\pi$-hole TtBs in supramolecular catalysis, focusing on two allotropic forms of carbon, i.e., $\mathrm{C}_{60}$ and carbon nanotubes. This part of the feature paper puts into perspective the bright future of this type of noncovalent bonding in catalysis.

\section{Results and Discussion}

\subsection{Crystal Engineering}

The position and size of the depleted areas of electron density on the surface of covalently bonded atoms depend on the type of covalent bond(s) formed by the atom (single or double/delocalized bonds). The $\sigma$ - and $\pi$-holes are located approximately along the vector of a single $\sigma$-bond and above and below the plane in $\pi$-bonds, respectively [41]. In the case of group 14, the heavier elements rarely form double 
bonds, thus $\sigma$-hole bonding is expected for $\mathrm{Si}$ to $\mathrm{Pb}$ atoms. However, both types of bonds are common for carbon that can, consequently, form both types of noncovalent bonding interactions. In fact, TtBs in carbonyl groups were described fifty years ago [42,43] and are common in organic compounds [44-46].

A representative characteristic of $\sigma$-hole interactions is their marked directionality that is directly related to the location and intensity of the $\sigma$-hole $[13,14,47,48]$. The linearity of this type of bonding has been confirmed by a multitude of CSD analyses [13,14,49-51] combined with computational studies [52,53]. It is also well known that the heavier elements (more polarizable) present more positive $\sigma$-holes, and thus have a stronger tendency to form interactions with electron rich atoms (see Figure 2 for fluorides of the tetrel elements as representative group). In fact, the lighter elements of groups 15 to 17 infrequently participate in $\sigma$-hole interactions (as electrophilic site) [50,51,54]. Moreover, the $\sigma$-hole intensity increases as the electron withdrawing ability of its substituents increases. Therefore, the $\sigma$-hole that is opposite the $\mathrm{C}-\mathrm{Y}$ bonds where $\mathrm{Y}=$ fluorine, cyano, or nitro, or a charged atom/group is favored over other substituents.

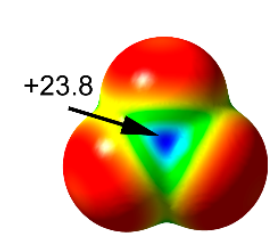

$\mathrm{CF}_{4}$

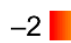

$+24$

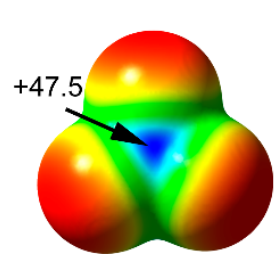

$\mathrm{SiF}_{4}$

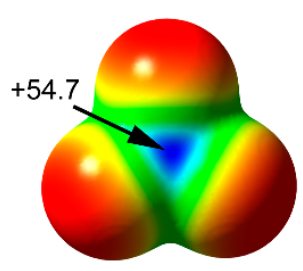

$\mathrm{GeF}_{4}$

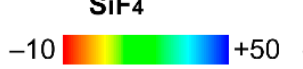

$-10$

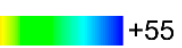

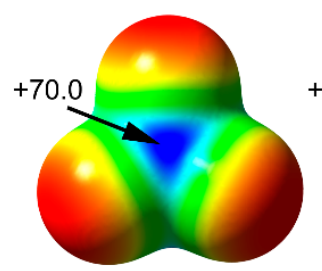

$\mathrm{SnF}_{4}$

$-20$

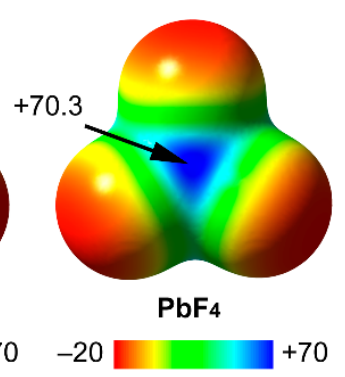

Figure 2. MEP surfaces of tetrafluorides of group 14 of elements. $\mathrm{CF}_{4}, \mathrm{SiF}_{4}$, and $\mathrm{GeF}_{4}$ at the B3LYP/6-311+G* level of theory and $\mathrm{SnF}_{4}$ and $\mathrm{PbF}_{4}$ at the B3LYP/LANL2DZ level of theory. Isosurface 0.001 a.u.

At this point, it is important to emphasize that other forces apart from the electrostatic component are also important in $\sigma$-and $\pi$-hole interactions, including some kinetic aspects. Ruedenberg evidenced the prominent role of kinetic energy in bond formation by partitioning the bond energy into the following three terms: (i) quasi-classical, (ii) promotion, and (iii) interference [55]. These three terms can be simplified as bonding and nonbonding, where the latter corresponds to the sum of quasi-classical and promotion. Ruedenberg's works clearly demonstrated that kinetic energy plays an important role in the formation of chemical bonds [56-58]. To this respect, the recent works by Sethio et al. [59] and Yannacone et al. [60] clearly demonstrated that focusing just on the $\sigma$ - and $\pi$-hole interactions leads to an incomplete picture, missing important facets of this type of noncovalent bonding.

Another important consideration is that the crystal environment is highly important and should be considered in crystal engineering computational studies. That is, periodicity is necessary in order to account for the crystal packing effect, which is not covered by the commonly used molecular cluster model [61].

\subsubsection{Neutral TtBs}

As commented above, electron withdrawing fluorine, cyano, and nitro substituents at the $\mathrm{C}\left(\mathrm{sp}^{3}\right)$ atom increase the magnitude of the $\sigma$-hole and favor the formation of TtB interactions. As exemplifying structures of fluorine substituent, Figure 3 shows partial views of the solid-state crystal packing of four compounds. The TtB has been described as the initial stage of a $\mathrm{S}_{\mathrm{N}} 2$ reaction [62] and, consequently, strong $\mathrm{TtBs}$ may change the geometry of the tetrel atom from tetrahedral to planar [63-65]. However, in the case of interactions involving the $\mathrm{C}_{\mathrm{sp}} 3-\mathrm{F}$ bond, the change of geometry is minimal because the fluorine atom, that is located opposite the electron rich atom, is not a good leaving group. Figure $3 \mathrm{a}$ shows the X-ray structure of the antitumor $\mathrm{N}, \mathrm{N}^{\prime}$-(pyridine-2,6-diyl)bis-naphthalenedicarboximide (refcode BOQGOD) [66] that presents a cocrystallized trifluoroacetic acid (TFA) that is in close contact 
with one $\mathrm{O}$-atom of the carboximide group. Interestingly, the $\mathrm{O}$-atom is located opposite the fluorine atom $\left(176^{\circ}\right)$ at a distance that is shorter than the sum of van der Waals radii of C and O (3.22 $\AA$ ). Interestingly, the $\mathrm{O}$-atom is also located over the $\mathrm{sp}^{2}$-hybridized $\mathrm{C}$-atom of the TFA molecule at a shorter distance $(2.887 \AA$ ), thus establishing a concurrent $\pi$-hole TtB. This type of bonding establishing concurrent $\sigma$ - and $\pi$-hole TtBs are also observed in the solid state of [bis(trifluoroacetoxy)iodo]benzene (refcode CEZBEO01) [67] that govern its assembly into infinite supramolecular one-dimensional (1D) chains. Furthermore, this behavior is observed in the solid state of fluoroformyl trifluoroacetyl disulfide (refcode PAWNUX) [68] that forms infinite 1D supramolecular chains where simultaneous and directional $\sigma$ - and $\pi$-hole TtBs are established (see Figure $3 \mathrm{~d}$ ). Finally, Figure $3 \mathrm{c}$ shows the $\mathrm{X}$-ray structure of trifluoromethyl-methoxy-chloro-iodine(III) that self-assembles, forming dimers where two directional TtBs are established (refcode GOTSUD) [69].

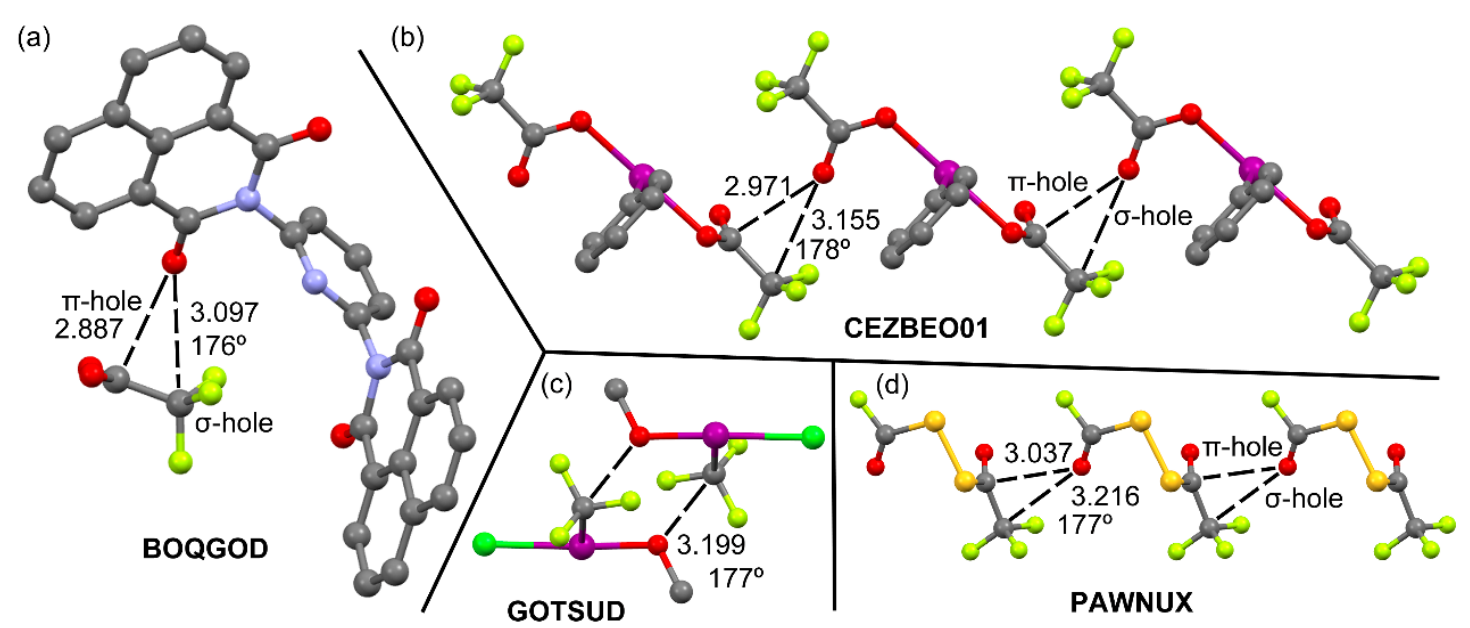

Figure 3. X-ray structures of Cambridge Structural Database (CSD) refcodes. (a) BOQGOD; (b) CEZBEO01; (c) GOTSUD; (d) PAWNUX. Distances in $\AA$ are given adjacent to the dashed lines used to represent the TtBs. H-atoms omitted for clarity.

Mooibroek's group evidenced experimentally [70] that a supramolecular synthon based on $\mathrm{sp}^{3}$-hybridized $\mathrm{C}$-atom could be used for predictable and directional tetrel bonding interactions and demonstrated its potential in crystal engineering [71]. Two structures are shown in Figure 4. TUQYAI structure corresponds to 6-oxaspiro[2.5] octane-1,1,2,2-tetracarbonitrile that forms infinite 1D supramolecular chains in the solid state where bifurcated TtBs are established (see Figure 4a). Interestingly, this 1D chain is preserved in the solid state of the 1,4-oxathiane solvate (see Figure 4b), where additional TtBs are formed between the axial lone pair at the O-atom of the 1,4-oxathiane and two C-atoms of the three-membered ring. It is worth mentioning that previous computational studies anticipated that the $\mathrm{sp}^{3}$ hybridized $\mathrm{C}(\mathrm{CN})_{2}$ centers present in 1,1,2,2-tetracyanocyclopropane exhibited a sterically accessible $\sigma$-hole $[39,40,72]$.

In a recent and excellent review by Resnati and co-workers [73], the ability of acetonitrile and nitromethane (specially coordinated to transition metals) to form TtBs was widely described, ranging from discrete dimers to infinite 1D chains. To further illustrate the ability of electron withdrawing $\mathrm{CN}$ group to activate the $\mathrm{sp}^{3}$-hybridized carbon atom as Lewis acid, three structures are given in Figures 5 and 6. In particular, Figure 4 represents the X-ray structures of chloro-tricyanomethane (CTCYME) [74] and bromo-tricyanomethane (BTCYME) [74]. In the former, directional TtBs govern the formation of trimeric assemblies where the electron rich atom $(\mathrm{N})$ is located exactly opposite the $\mathrm{C}-\mathrm{Cl}$ bond (see Figure $4 \mathrm{a}$ ). The sum of $\mathrm{C}$ and $\mathrm{N}$ van der Waals (vdW) radii is $3.25 \AA$, very similar to the N...C distance in CTCYME. Unexpectedly the $\mathrm{N}$ is located opposite the $\mathrm{Cl}$ atom, instead of the $\mathrm{CN}$ group. This behavior, where the electron rich atom is located opposite the most polarizable atom instead of the most electron-withdrawing one has been observed and described in chalcogen bonding [75]. In the BTCYME, the N-atom is located opposite the 
$\mathrm{CN}$ group, however, the distance is significantly longer and the angle smaller (less directional), thus, indicating a very weak or non-existent TtB. In contrast, this structure forms short $\mathrm{Br} \cdots \mathrm{N}$ halogen bonds $(3.031 \AA$ ) due to the stronger ability of bromine with respect to chlorine as a halogen bond donor.

(a)

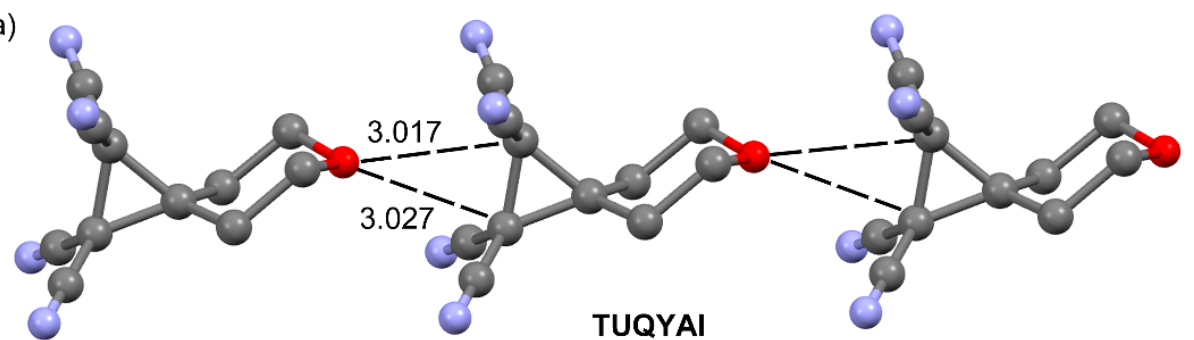

(b)

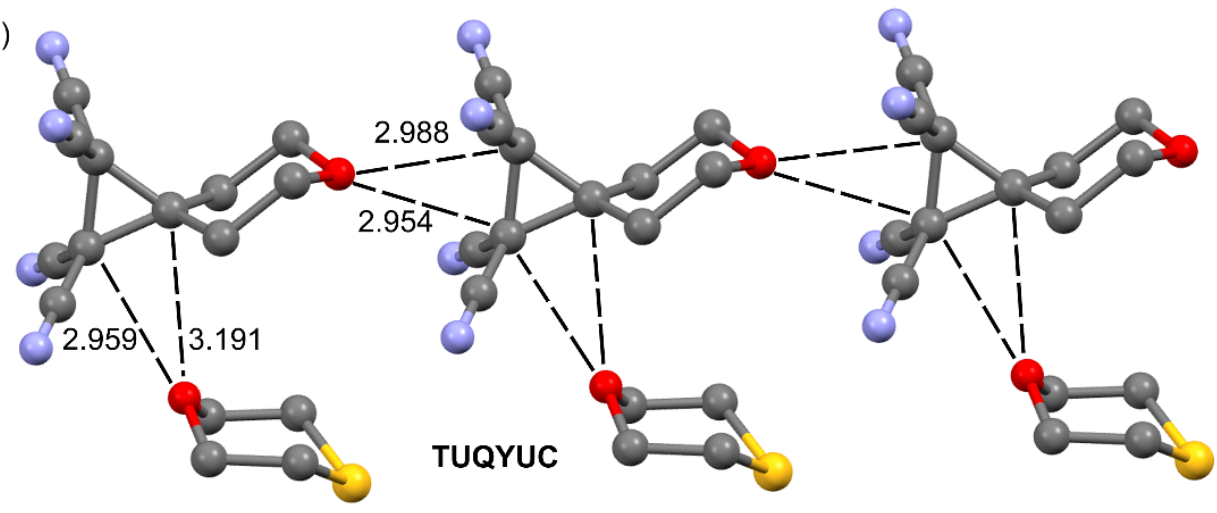

Figure 4. X-ray structures of CSD refcodes. (a) TUQYAI; (b) TUQYUC. Distances in $\AA$ are given adjacent to the dashed lines used to represent the TtBs. H-atoms omitted for clarity.

(a)

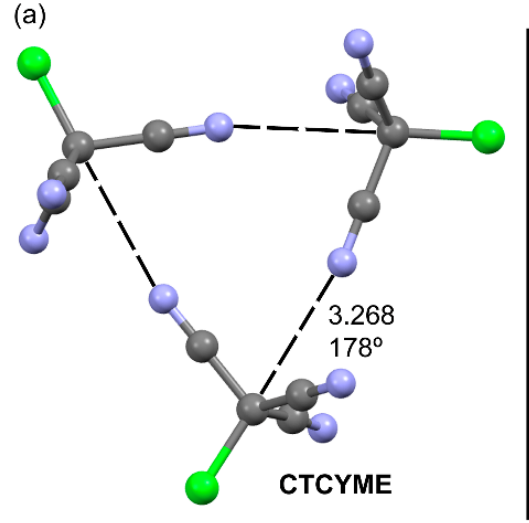

(b)

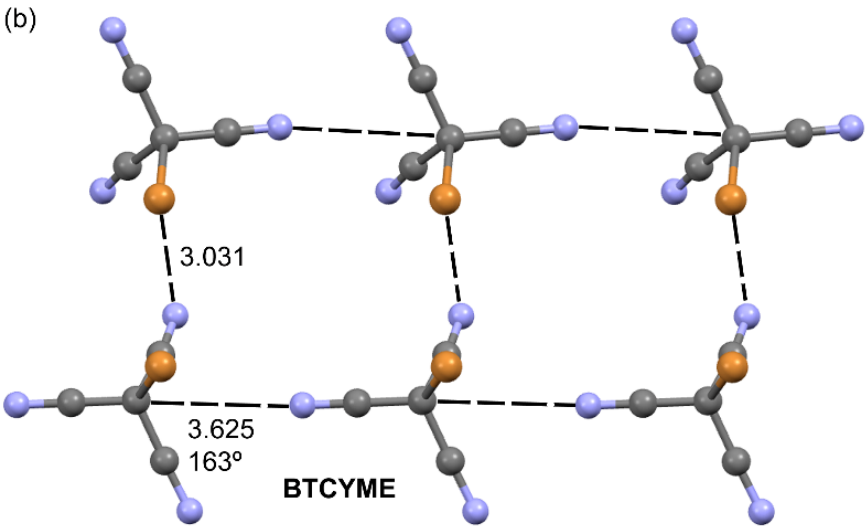

Figure 5. X-ray structures of CSD refcodes. (a) CTCYME; (b) BTCYME. Distances in $\AA$ are given adjacent to the dashed lines used to represent the TtBs. 


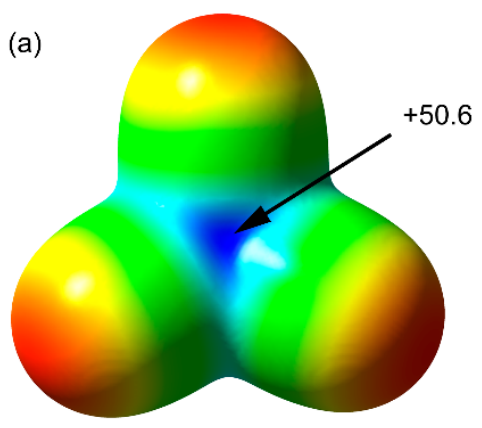

(b)

Figure 6. (a) MEP surface of tetracyanomethane at the B3LYP/6-311+G* level of theory. Isosurface 0.001 a.u.; (b) X-ray structure of CSD refcodes TCYMET. Distance in $\AA$.

It is interesting to note that in the case of tetracyanomethane (TCYMET, see Figure 5) [76], TtBs assemble the molecule into 1D supramolecular chains in the solid state. In this case, the distance is shorter than the sum of $\mathrm{vdW}$ radii and the interaction is perfectly linear $\left(180^{\circ}\right)$. It is worth mentioning that this molecule presents very positive $\sigma$-holes (see Figure 5a), comparable to those of $\mathrm{GeF}_{4}$, thus explaining the formation of the perfectly directional and short TtBs in its X-ray solid state structure.

The existence of TtBs is also quite common in 1-methyl- $1 H$-tetrazol derivatives, although it has not been previously analyzed in the literature. Figure 7 shows several examples to illustrate this circumstance. The modest electron withdrawing effect of tetrazole ring can be significantly enhanced by its coordination to transition metals or protonation. For instance, in structures CABFET [77] and CABFIX [77] the 1-methyl-1H-tetrazole-5-thiolato ligands are coordinated to Hg-atoms and the methyl groups establish two symmetrically equivalent TtBs forming self-assembled dimers that further propagate the molecules into $1 \mathrm{D}$ infinite chains. The $\mathrm{C} \cdots \mathrm{N}$ interactions are very directional $\left(175^{\circ}-179^{\circ}\right)$ and shorter than the sum of vdW radii (3.25 $\AA$ ). Figure 7c shows the simplified view of DISBAK [78] $\mathrm{X}$-ray structure, where one $\mathrm{O}$-atom of octamolibdate moiety is located at the extension of the $\mathrm{N}-\mathrm{C}$ bond, establishing a short and directional TtB. In the case of 5-amino-1-methyl-1H-tetrazolium picrate (refcode GAVXUX) [79], the O-atom belonging to the nitro group is also located at the prolongation of the $\mathrm{N}-\mathrm{C}$ bond and presents a quite short interaction, likely due to the additional electrostatic attraction between the counterions.
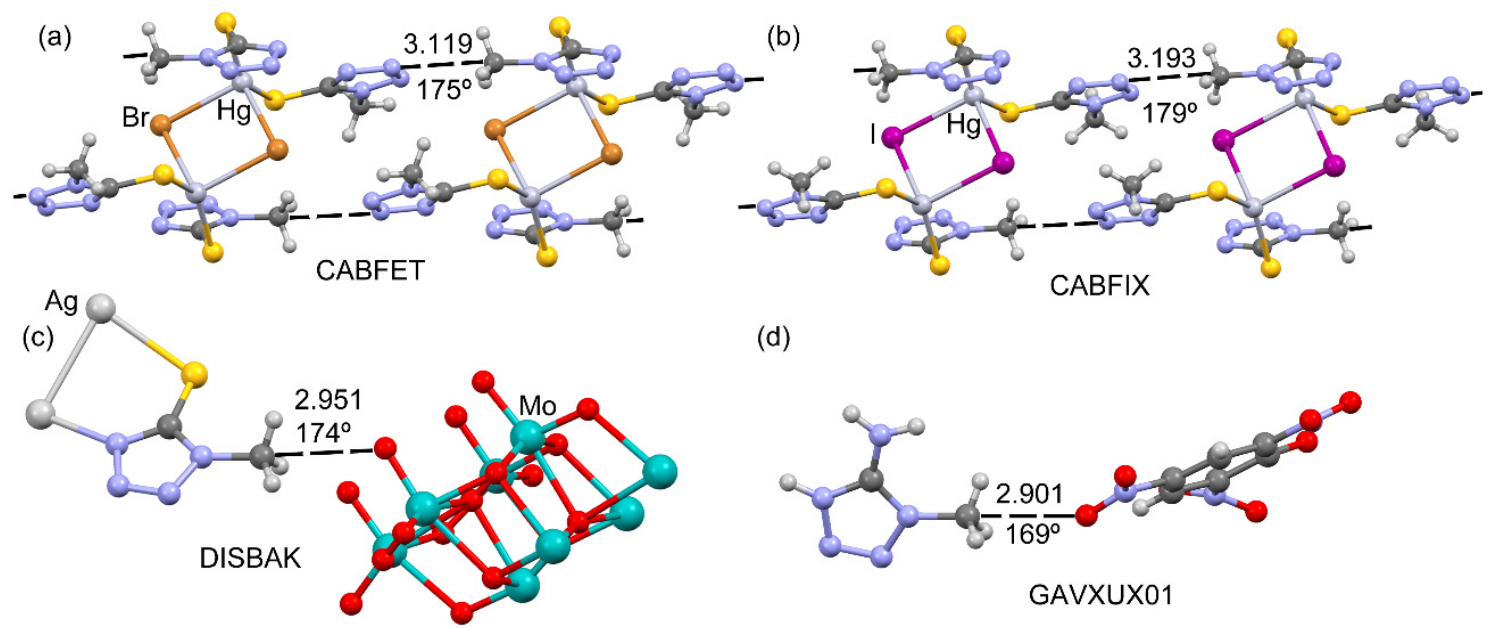

(d)

Figure 7. X-ray structures of CSD refcodes. (a) CABFET; (b) CABFIX; (c) DISBAK; (d) GAVXUX01. Distances in $\AA$ are given adjacent to the dashed lines used to represent the TtBs.

It has also been demonstrated that TtBs are important in the crystal packing of dimethyl-formamide (DMF) transition metal complexes [80]. A marked decrease of electron density at the amide group 
occurs when the oxygen of formamide is bound to a transition metal cation (Figure 8), thus enhancing its electron withdrawing ability. This favors the TtB formation as shown in AJESAJ04 [80] where the $\mathrm{N}$-atom of the $\mu_{1,5}$-dicyanamido bridge is the TtB acceptor. These TtBs interconnect the 1D Co(II) coordination polymers.

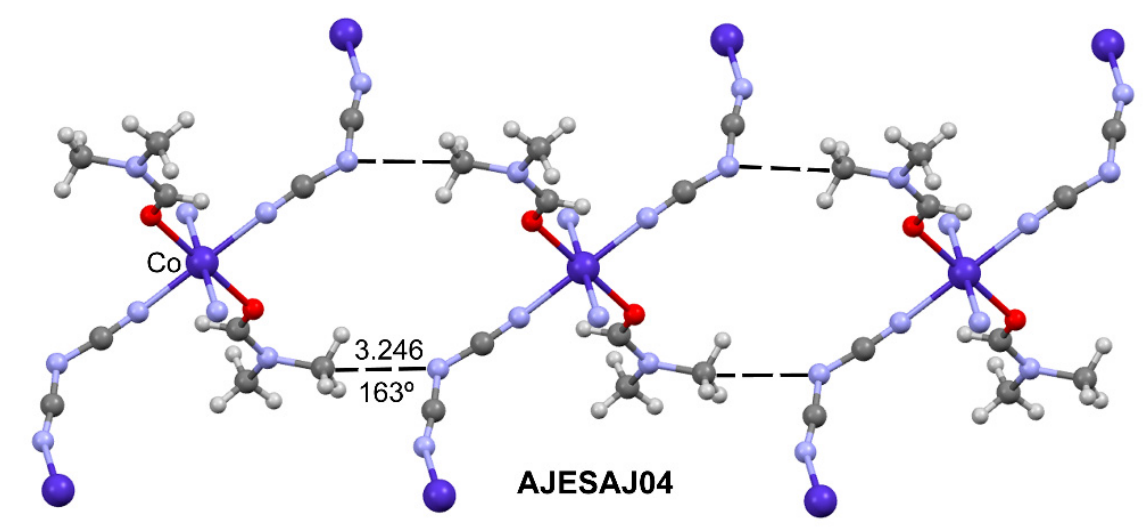

Figure 8. X-ray structures of CSD refcodes AJESAJ06. Distance in $\AA$ is given adjacent to the dashed lines used to represent the TtBs.

\subsubsection{Charge assisted TtBs}

Obviously, the TtB interaction is enhanced whether or not the $\sigma$-hole donor carbon atom is directly bonded to a charged atom (charge assisted TtB). Three examples are given in Figure 9 (see ref. [73] for a more comprehensive treatment) where the $\mathrm{C}_{\mathrm{sp}} 3$-bonded charged atom is an element of the second row $\left(\mathrm{N}^{+}, \mathrm{O}^{+}\right.$, or $\left.\mathrm{S}^{+}\right)$of the periodic table. The methyl-quinolinium moiety in YOWKEB [81] interacts with the iodide counter-anion by means of a short and directional $\mathrm{TtB}\left(172^{\circ}\right)$. Similarly, a carbon atom of the trimethyloxonium cation in FIHLAM structure [82] interacts with an F-atom of tetrakis[1,1,1,3,3,3-hexafluoro-2-(trifluoromethyl)propan-2-olato]-aluminium anion via a short TtB. In LANTAX [83] structure, the C-atom of trimethylsulfonium cation is in short contact with the I-atom of 1-amino-6-fluoro-2,3,4,5,7,8,9,10,11,12-decaiodo-1-carba-closo-dodecaborate counter-ion.
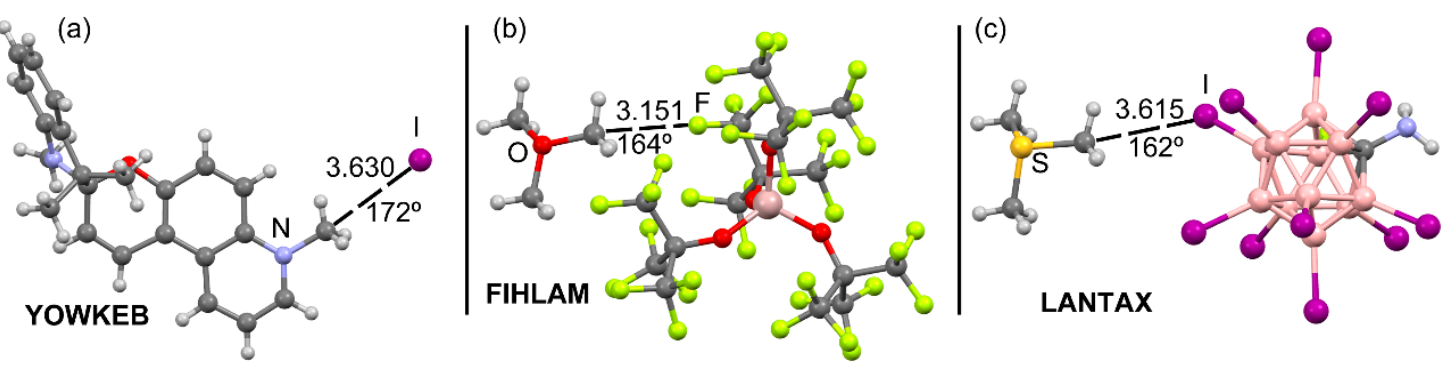

Figure 9. X-ray structures of CSD refcodes. (a) YOWKEB; (b) FIHLAM; (c) LANTAX. Distances in $\AA$ are given adjacent to the dashed lines used to represent the TtBs.

Figure 10 shows additional examples of charge assisted TtBs in X-ray structures where the carbon atom is covalently bonded to elements of third and fourth row $\left(\mathrm{P}^{+}, \mathrm{Se}^{+}\right.$and $\left.\mathrm{Te}^{+}\right)$of the periodic table. In LOQYEX [84], the trimethylselenonium cation interacts with one of the adjacent $\left[\mathrm{ZnCl}_{4}\right]^{2-}$ counter-ion by means of a short and directional TtB (the $\mathrm{Cl}$ atom is located opposite the Se ${ }^{+}-\mathrm{C}$ bond. Similarly, the nitrogen atom of the thiocyanate anion in HUHBOB (see Figure 10b) is located almost perfectly on the extension of the $\mathrm{Te}^{+}-\mathrm{C}$ bond $\left(177^{\circ}\right)$. Finally, in DOSPUW, the $\mathrm{sp}^{3}$-hybridized carbon atom of the methyltriphenylphosphonium cation is in close contact with one bridging chlorido ligand of the tris( $\mu_{2}$-chloro)-dicarbonyl-dichloro-bis(triphenylphosphine)-di-ruthenium(II) complex. 
(a)

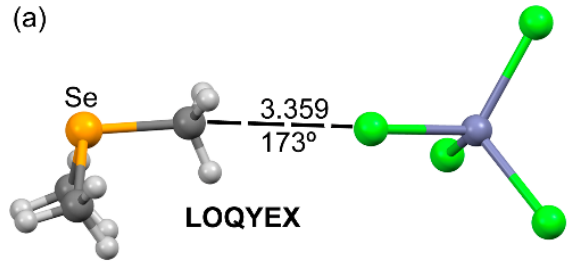

(b)

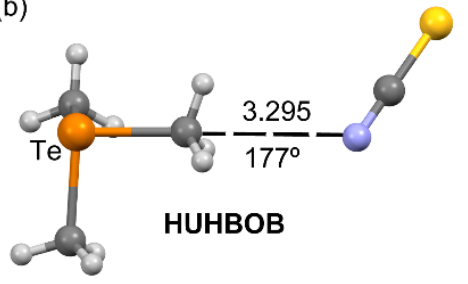

(c)

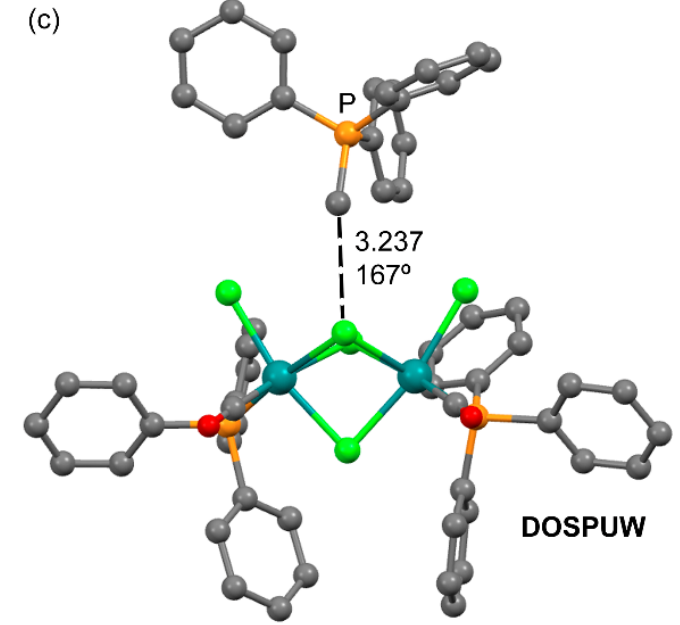

Figure 10. X-ray structures of CSD refcodes. (a) LOQYEX; (b) HUHBOB; (c) DOSPUW. Distances in $\AA$ are given adjacent to the dashed lines used to represent the TtBs.

\subsection{Anion- $\pi$ ( $\pi$-Hole) Catalysis with Carbon Allotropes}

Recent investigations of the ability of fullerenes and nanotubes to catalyze organic reactions by means of $\pi$-hole interactions are described in this subsection of the feature paper. In the literature, the interaction of electron rich atoms with aromatic surfaces, or any $\pi$-system in general, is known as lone pair(lp) $-\pi$ or anion $-\pi$ depending on the electron donor (Lewis base or anion, respectively). Contrariwise to cation $-\pi$ interactions where the name is based on the electron accepting atom (as in hydrogen bonding or other $\sigma$-hole interactions), the anion or lp- $\pi$ terminology is based on the electron rich atom. Therefore, the names anion $-\pi$ or $l p-\pi$ interactions do not follow the recommendation that the IUPAC has adopted for hydrogen [85], halogen [24], and chalcogen [25] bonds. Nevertheless, anion $-\pi$ or lp $-\pi$ are well established and commonly used terms. Regardless, both interactions can be considered to be subclasses of $\pi$-hole interactions. Electron deficient rings such as hexafluorobenzene, see Figure 11, present positive $\pi$-holes above and below the center of the ring, thus, adequate for interacting with electron rich atoms. Since the electron acceptor atoms (carbon in this case) belong to group 14, the interaction of hexafluorobenzene with anions or lone pair donor atoms can be termed as $\pi$-hole TtB. In the case of heteroaromatic rings such as electron deficient azines, the interaction cannot be easily termed since atoms belonging to two different groups of the periodic table participate as electron acceptors. In this case, the generic name $\pi$-hole is likely more convenient to refer to this type of bonding.

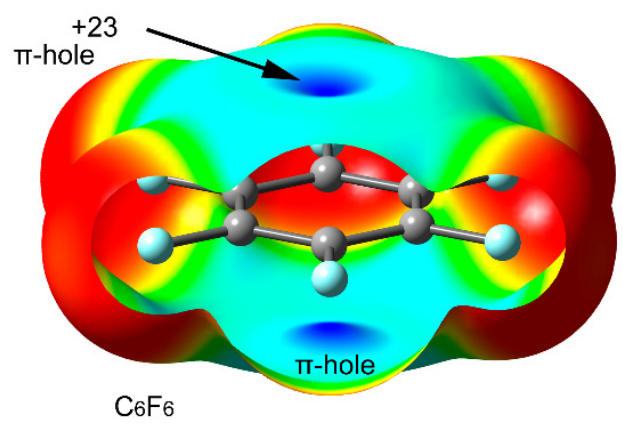

Figure 11. MEP surface of hexafluorobenzene at the B3LYP/6-31+G* (isosurface 0.001 a.u.). The energy value at the $\pi$-hole is given in $\mathrm{kcal} / \mathrm{mol}$. 
Fullerenes have been used in the literature $[86,87]$ to investigate anion $-\pi(\pi$-hole) catalysis as a proof of concept. This is because it offers the purest $\pi$-system to explore the importance of polarizability in this type of catalysis. That is, the absence of substituents, dipole, and quadrupole moments and the perspective of polarizability-induced catalysis has attracted the interest of $C_{60}$, likely the most popular carbon allotrope, as catalyst. The MEP surface of $\mathrm{C}_{60}$ is represented in Figure 12, showing highly localized areas of positive potential, resembling a golf ball. These $\pi$-holes are slightly more positive over the center of the six membered than over the five-membered rings. Matile and co-workers showed that these $\pi$-holes provided unique selectivities to a series of catalysts based on $\mathrm{C}_{60}$ fullerenes [86,87]. The catalyzed chemical transformations included anionic Diels-Alder reactions and selective acceleration of disfavored enolate additions versus decarboxylation reactions. In both reactions, the anionic transition state was stabilized by $\mathrm{O} \cdots \pi$-hole interactions. The pioneering investigations by Matile and co-workers have opened an attractive and exciting new perspective for the use of carbon allotropes in catalysis.

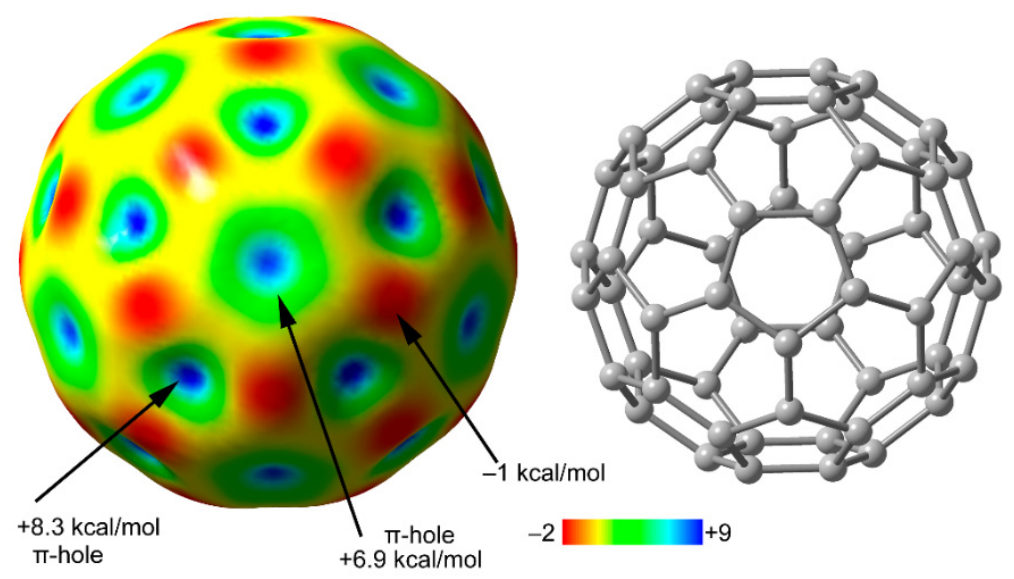

Figure 12. (Left) MEP surface of $C_{60}$ at the B3LYP/6-31+G* (isosurface 0.001 a.u.); (Right) The $C_{60}$ is represented using the same orientation utilized to plot the MEP surface.

Figure 13 represents the MEP surface of a model or single wall carbon nanotube (SWCNT) of size and symmetry $(8,0)$ and three belts of length. The surface shows the existence of $\pi$-holes over the center of the six membered rings. This model nanotube presents fluorine substituents at both ends, thus, increasing the MEP values at the $\pi$-holes. Matile and co-workers provided experimental evidence of $\pi$-hole catalysis on carbon nanotubes [88]. Interestingly, they showed that multi walled carbon nanotubes (MWCNTs) outperform SWCNTs due to cooperativity effects between $\pi-\pi$ interactions (established between the concentric nanotubes) and anion $-\pi$ ( $\pi$-hole) interactions. Due to the metal/semiconductor character of carbon nanotubes, this field of research can be focused to the study of the effect of conducting nanotubes on the catalytic performance.

Figure 14 represents the catalyst (pictorial representation) and reaction used by Matile and coworkers to demonstrate the importance of $\pi$-hole interaction in supramolecular catalysis. The reaction used is the addition of malonic half thioester (MAHT) to $\beta$-nitrostyrene (see Figure 14b). The formation of addition product $\mathbf{A}$ is a competitive reaction with the decarboxylation reaction (formation of $\mathbf{D}$ ). If the enol form of MAHT is stabilized by a $\pi$-hole interaction with the catalyst surface, the amount of addition product increases with respect to the non-catalyzed reaction. In contrast, if the enol form is not stabilized, the keto form predominates, and the amount of addition product does not increase. Interesting, experimental results have shown [88] that the A/D ratio increases by a factor of 6.8 in the case of the utilization of SWCNTs and by an impressive factor of 25 in the case of MWCNTs with respect to the uncatalyzed reaction 


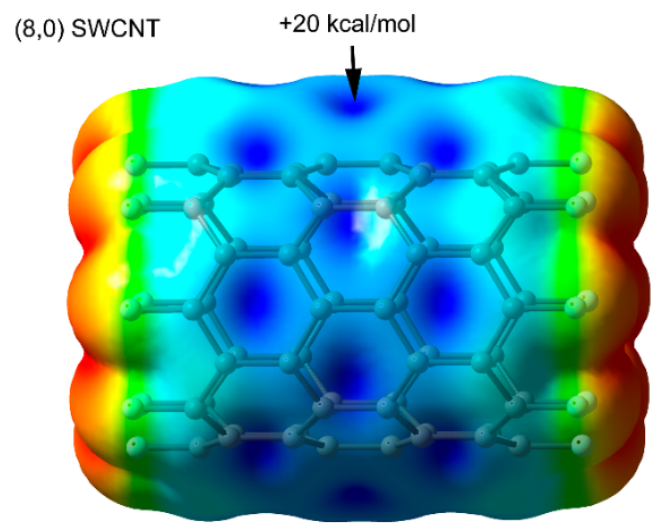

Figure 13. MEP surface of $(8,0)$ SWCNT at the B3LYP/6-31+ $\mathrm{G}^{*}$ (isosurface 0.001 a.u.) saturated with fluorine at both ends.

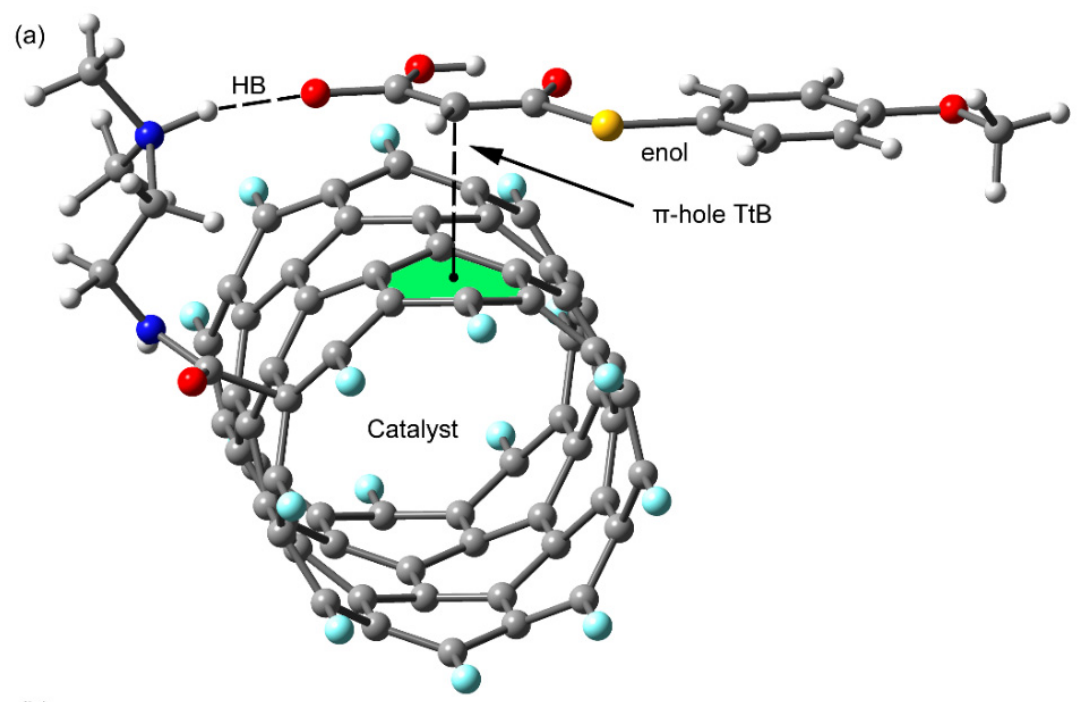

(b)

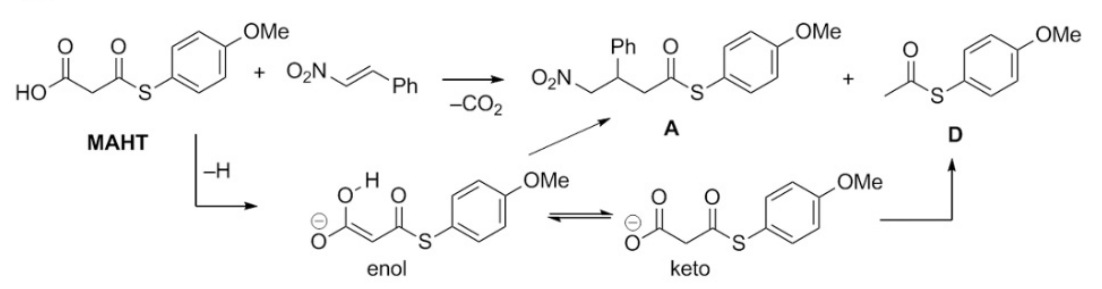

Figure 14. (a) Representation of a generic nanotube functionalized with a tertiary amine and a linker and interacting with MAHT interacting by a combination of HB and anion $-\pi(\pi$-hole TtB); (b) Reaction of MAHT with $\beta$-nitrostyrene to yield the mixture of addition (A) and decarboxylation (D) products.

\section{Conclusions}

In the first part, this feature article gathers selected CSD structures in which $\mathrm{C}\left(\mathrm{sp}^{3}\right)$ atoms participate in TtBs. As already described for other $\sigma$-hole interactions, a linear directionality is a marked characteristic of TtBs involving the lighter tetrel atom. In fact, when the $\sigma$-hole donor $\mathrm{C}$-atom belongs to a methyl or methylene group, the deviation from linearity may imply the formation of HBs instead of TtBs. The structures discussed here along with others provided in another review [73] unambiguously demonstrate that interactions involving $\mathrm{C}\left(\mathrm{sp}^{3}\right)$ sites are relevant in crystal engineering.

The second part of this feature article highlights recent reports where two different allotropic forms of carbon have been used in supramolecular catalysis to take advantage of the multiple $\pi$-holes present on the surface of fullerenes and nanotubes. The utilization of anion- $\pi$ (or $\pi$-hole TtBs) in 
catalysis using these two forms of carbons opens attractive new perspectives for the utilization of $\pi$-hole supramolecular catalysis in other fullerenes and graphene.

Funding: This research was funded by MICIU/AEI, grant number CTQ2017-85821-R, FEDER funds.

Conflicts of Interest: The author declares no conflict of interest.

\section{References}

1. Feringa, B.L. The Art of Building Small: From Molecular Switches to Motors (Nobel Lecture). Angew. Chem. Int. Ed. 2017, 56, 11060-11078. [CrossRef]

2. Newberry, R.W.; Raines, R.T. The $n \rightarrow \pi^{*}$ Interaction. Acc. Chem. Res. 2017, 50, 1838-1846. [CrossRef] [PubMed]

3. Varughese, S. Non-covalent routes to tune the optical properties of molecular materials. J. Mater. Chem. C 2014, 2, 3499-3516. [CrossRef]

4. Scheiner, S. Noncovalent Forces; Springer International Publishing: Cham, Switzerland, 2015. [CrossRef]

5. Yuan, C.; Ji, W.; Xing, R.; Li, J.; Gazit, E.; Yan, X. Hierarchically oriented organization in supramolecular peptide crystals. Nat. Rev. Chem. 2019, 3, 567-588. [CrossRef]

6. $\quad$ Spackman, P.R.; Yu, L.-J.; Morton, C.J.; Parker, M.W.; Bond, C.S.; Spackman, M.A.; Jayatilaka, D.; Thomas, S.P. Bridging Crystal Engineering and Drug Discovery by Utilizing Intermolecular Interactions and Molecular Shapes in Crystals. Angew. Chem. Int. Ed. 2019, 58, 16780-16784. [CrossRef]

7. Daze, K.D.; Hof, F. The Cation $-\pi$ Interaction at Protein-Protein Interaction Interfaces: Developing and Learning from Synthetic Mimics of Proteins That Bind Methylated Lysines. Acc. Chem. Res. 2013, 46, 937-945. [CrossRef]

8. Tuikka, M.; Hirva, P.; Rissanen, K.; Korppi-Tommola, J.; Haukka, M. Halogen bonding-A key step in charge recombination of the dye-sensitized solar cell. Chem. Commun. 2011, 47, 4499-4501. [CrossRef]

9. Song, P.; Wang, H. High-Performance Polymeric Materials through Hydrogen-Bond Cross-Linking. Adv. Mat. 2020, 32, 1901244. [CrossRef]

10. Molcanov, K.; Milasinovic, V.; Kojic-Prodic, B. Contribution of Different Crystal Packing Forces in $\pi$-Stacking: From Noncovalent to Covalent Multicentric Bonding. Cryst. Growth Des. 2019, 19, 5967-5980. [CrossRef]

11. Frontera, A.; Gamez, P.; Mascal, M.; Mooinbroek, T.J.; Reedijk, J. Putting Anion- $\pi$ Interactions Into Perspective. Angew. Chem. Int. Ed. 2011, 50, 9564-9583. [CrossRef]

12. Yamada, S. Cation $-\pi$ Interactions in Organic Synthesis. Chem. Rev. 2018, 118, 11353-11432. [CrossRef] [PubMed]

13. Politzer, P.; Murray, J.S. An Overview of Strengths and Directionalities of Noncovalent Interactions: $\sigma$-Holes and $\pi$-Holes. Crystals 2019, 9, 165. [CrossRef]

14. Politzer, P.; Murray, J.S.; Clark, T.; Resnati, G. The $\sigma$-hole revisited. Phys. Chem. Chem. Phys. 2017, 19, 32166-32178. [CrossRef] [PubMed]

15. Bauzá, A.; Alkorta, I.; Elguero, J.; Mooibroek, T.J.; Frontera, A. Spodium Bonds: Noncovalent Interactions Involving Group 12 Elements. Angew. Chem. Int. Ed. 2020, 59, 17482-17487. [CrossRef]

16. Alkorta, I.; Elguero, J.; Frontera, A. Not Only Hydrogen Bonds: Other Noncovalent Interactions. Crystals 2020, 10, 180. [CrossRef]

17. Frontera, A. Noble Gas Bonding Interactions Involving Xenon Oxides and Fluorides. Molecules 2020, 25, 3419. [CrossRef]

18. Gomila, R.M.; Frontera, A. Covalent and Non-covalent Noble Gas Bonding Interactions in $\mathrm{XeF}_{\mathrm{n}}$ Derivatives $(\mathrm{n}=2-6)$ : A Combined Theoretical and ICSD Analysis. Front. Chem. 2020, 8, 395. [CrossRef]

19. Bauzá, A.; Frontera, A. $\sigma / \pi$-Hole noble gas bonding interactions: Insights from theory and experiment. Coord. Chem. Rev. 2020, 404, 213112. [CrossRef]

20. Cavallo, G.; Metrangolo, P.; Pilati, T.; Resnati, G.; Terraneo, G. Naming Interactions from the Electrophilic Site. Cryst. Growth Des. 2014, 14, 2697-2702. [CrossRef]

21. Terraneo, G.; Resnati, G. Bonding Matters. Cryst. Growth Des. 2017, 17, 1439-1440. [CrossRef]

22. Frontera, A.; Bauzà, A. Regium- $\pi$ bonds: An Unexplored Link between Noble Metal Nanoparticles and Aromatic Surfaces. Chem. Eur. J. 2018, 24, 7228-7234. [CrossRef] [PubMed] 
23. Legon, A. Tetrel, pnictogen and chalcogen bonds identified in the gas phase before they had names: A systematic look at non-covalent interactions. Phys. Chem. Chem. Phys. 2017, 19, 14884-14896. [CrossRef] [PubMed]

24. Desiraju, G.R.; Ho, P.S.; Kloo, L.; Legon, A.C.; Marquardt, R.; Metrangolo, P.; Politzer, P.; Resnati, G.; Rissanen, K. Definition of the halogen bond (IUPAC Recommendations 2013). Pure Appl. Chem. 2013, 85, 1711-1713. [CrossRef]

25. Aakeroy, C.B.; Bryce, D.L.; Desiraju, G.R.; Frontera, A.; Legon, A.C.; Nicotra, F.; Rissanen, K.; Scheiner, S.; Terraneo, G.; Metrangolo, P.; et al. Definition of the chalcogen bond (IUPAC Recommendations 2019). Pure Appl. Chem. 2019, 91, 1889-1892. [CrossRef]

26. Michalczyk, M.; Zierkiewicz, W.; Scheiner, S. Triel-Bonded Complexes between $\operatorname{TrR}_{3}(\operatorname{Tr}=B, A l, G a ; R=H, F$, $\mathrm{Cl}, \mathrm{Br}, \mathrm{CH}_{3}$ ) and Pyrazine. Chem. Phys. Chem. 2018, 19, 3122-3133. [CrossRef]

27. Bauzá, A.; Mooibroek, T.J.; Frontera, A. Tetrel-Bonding Interaction: Rediscovered Supramolecular Force? Angew. Chem. Int. Ed. 2013, 52, 12317-12321. [CrossRef]

28. Bauzá, A.; Mooibroek, T.J.; Frontera, A. Tetrel Bonding Interactions. Chem. Rec. 2016, 16, 473-487. [CrossRef]

29. Scilabra, P.; Terraneo, G.; Daolio, A.; Baggioli, A.; Famulari, A.; Leroy, C.; Bryce, D.L.; Resnati, G. 4,4'-Dipyridyl Dioxide. $\mathrm{SbF}_{3}$ Cocrystal: Pnictogen Bond Prevails over Halogen and Hydrogen Bonds in Driving Self-Assembly. Cryst. Growth Des. 2020, 20, 916-922. [CrossRef]

30. Scheiner, S. The Pnicogen Bond: Its Relation to Hydrogen, Halogen, and Other Noncovalent Bonds. Acc. Chem. Res. 2013, 46, 280-288. [CrossRef]

31. Mikuriya, M.; Okawa, H.; Kidam, S. Binuclear metal complexes. XXXII [1]. Further studies of binuclear copper(II) complexes with N-(2-alkylthioethyl)-3-aminopropanol: Synthesis, Spectral and magnetic properties and the crystal structure. Inorg. Chem. Acta 1980, 42, 233-239. [CrossRef]

32. Healy, P.C.; Kildea, J.D.; White, A.H. Lewis-Base Adducts of Group 11 Metal(I) Compounds. XLIV. Synthesis and Conformational Systematics of 1:1 Copper(I) Halide Nitrogen Base Adducts as [(N-base)CuX ${ }_{2} \mathrm{Cu}(\mathrm{N}-$ base $)$ ] Dimers $(\mathrm{X}=\mathrm{Cl}, \mathrm{Br}, \mathrm{I})$ and $[(\mathrm{N}-\mathrm{Base}) \mathrm{CuX}$ ] Monomers $(\mathrm{X}=\mathrm{Cl}, \mathrm{Br})$. Aust. J. Chem. 1989, 42, 137-148. [CrossRef]

33. Jones, P.G.; Ahrens, B. Gold(I) complexes with amine ligands. 3 Competition between auriophilic and hydrogen bonding interactions in dimeric species. New J. Chem. 1998, 22, 1041-1042. [CrossRef]

34. Wang, R.; Yang, S.; Li, Q. Coinage-Metal Bond between [1.1.1]Propellane and M2/MCl/MCH3 (M = Cu, Ag, and $\mathrm{Au}$ ): Cooperativity and Substituents. Molecules 2019, 24, 2601. [CrossRef]

35. Groom, C.R.; Bruno, I.J.; Lightfoot, M.P.; Ward, S.C. The Cambridge Structural Database. Acta Cryst. 2016, B72, 171-179. [CrossRef]

36. Murray, J.S.; Politzer, P. $\sigma-H o l e s$ and Si $\cdots \mathrm{N}$ intramolecular interactions. J. Mol. Mod. 2019, 25, 101. [CrossRef]

37. Lu, J.; Scheiner, S. Effects of Halogen, Chalcogen, Pnicogen, and Tetrel Bonds on IR and NMR Spectra. Molecules 2019, 24, 2822. [CrossRef]

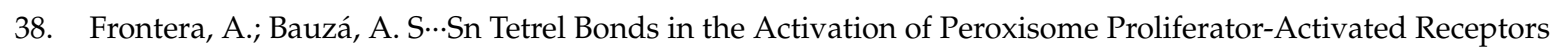
(PPARs) by Organotin Molecules. Chem. Eur. J. 2018, 24, 16582-16587. [CrossRef]

39. Escudero-Adán, E.C.; Bauzà, A.; Frontera, A.; Ballester, P. Nature of Noncovalent Carbon-Bonding Interactions Derived from Experimental Charge-Density Analysis. Chem. Phys. Chem. 2015, 16, 2530-2533. [CrossRef]

40. Bauzà, A.; Frontera, A.; Mooibroek, T.J. 1,1,2,2-Tetracyanocyclopropane (TCCP) as supramolecular synthon. Phys. Chem. Chem. Phys. 2016, 18, 1693-1698. [CrossRef]

41. Murray, J.S.; Lane, P.; Clark, T.; Riley, K.E.; Politzer, P. $\sigma$-Holes, $\pi$-holes and electrostatically-driven interactions. J. Mol. Mod. 2012, 18, 541-548. [CrossRef]

42. Bürgi, H.B.; Dunitz, J.D.; Shefter, E. Geometrical reaction coordinates. II. Nucleophilic addition to a carbonyl group. J. Am. Chem. Soc. 1973, 95, 5065-5067. [CrossRef]

43. Bürgi, H.B.; Dunitz, J.D. From crystal statics to chemical dynamics. Acc. Chem. Res. 1983, 16, $153-161$. [CrossRef]

44. Persch, E.; Dumele, O.; Diederich, F. Molecular Recognition in Chemical and Biological Systems. Angew. Chem. Int. Ed. 2015, 54, 3290-3327. [CrossRef] [PubMed]

45. Paulini, R.; Müller, K.; Diederich, F. Orthogonal Multipolar Interactions in Structural Chemistry and Biology. Angew. Chem. Int. Ed. 2005, 44, 1788-1805. [CrossRef] [PubMed]

46. Allen, F.H.; Baalham, C.A.; Lommerse, J.M.; Raithby, P.R. Carbonyl-Carbonyl Interactions can be Competitive with Hydrogen Bonds. Acta Cryst. 1998, B54, 320-329. [CrossRef] 
47. Priimagi, A.; Cavallo, G.; Metrangolo, P.; Resnati, G. The Halogen Bond in the Design of Functional Supramolecular Materials: Recent Advances. Acc. Chem. Res. 2013, 48, 2686-2695. [CrossRef]

48. Bauzá, A.; Mooinbroek, T.J.; Frontera, A. The Bright Future of Unconventional $\sigma / \pi$-Hole Interactions. Chem. Phys. Chem. 2015, 16, 2496-2517. [CrossRef]

49. Scilabra, P.; Terraneo, G.; Resnati, G. The Chalcogen Bond in Crystalline Solids: A World Parallel to Halogen Bond. Acc. Chem. Res. 2019, 52,1313-1324. [CrossRef]

50. Scilabra, P.; Terraneo, G.; Resnati, G. Fluorinated elements of Group 15 as pnictogen bond donor sites. J. Fluor. Chem. 2017, 203, 62-74. [CrossRef]

51. Scilabra, P.; Kumar, V.; Ursini, M.; Resnati, G. Close contacts involving germanium and tin in crystal structures: Experimental evidence of tetrel bonds. J. Mol. Mod. 2018, 24, 37. [CrossRef]

52. Mundlapati, V.R.; Sahoo, D.K.; Bhaumik, S.; Jena, S.; Chandrakar, A.; Biswal, H.S. Noncovalent Carbon-Bonding Interactions in Proteins. Angew. Chem. Int. Ed. 2018, 57, 16496-16500. [CrossRef] [PubMed]

53. Mooibroek, T.J. Intermolecular Non-Covalent Carbon-Bonding Interactions with Methyl Groups: A CSD, PDB and DFT Study. Molecules 2019, 24, 3370. [CrossRef]

54. Metrangolo, P.; Murray, J.S.; Pilati, T.; Politzer, P.; Resnati, G.; Terraneo, G. The fluorine atom as a halogen bond donor, viz. a positive site. CrystEngComm 2011, 13, 6593-6596. [CrossRef]

55. Ruedenberg, K. The physical nature of the chemical bond. Rev. Mod. Phys. 1962, 34, 326-352. [CrossRef]

56. Feinberg, M.J.; Ruedenberg, K. Paradoxical Role of the Kinetic-Energy Operator in the Formation of the Covalent Bond. J. Chem. Phys. 1971, 54, 1495-1511. [CrossRef]

57. Feinberg, M.J.; Ruedenberg, K. Heteropolar One-Electron Bond. J. Chem. Phys. 1971, 55, 5804-5818. [CrossRef]

58. Feinberg, M.J.; Ruedenberg, K.; Mehler, E.L. The Origin of Binding and Antibinding in the Hydrogen Molecule-lon. Adv. Quantum Chem. 1970, 5, 27-98. [CrossRef]

59. Sethio, D.; Oliveira, V.; Kraka, E. Quantitative Assessment of Tetrel Bonding Utilizing Vibrational Spectroscopy. Molecules 2018, 23, 2763. [CrossRef]

60. Yannacone, S.; Freindorf, M.; Tao, Y.; Zou, W.; Kraka, E. Local Vibrational Mode Analysis of $\pi-$ Hole Interactions between Aryl Donors and Small Molecule Acceptors. Crystals 2020, 10, 556. [CrossRef]

61. Tao, Y.; Qiu, Y.; Zou, W.; Nanayakkara, S.; Yannacone, S.; Kraka, E. In Situ Assessment of Intrinsic Strength of X-I...OA-Type Halogen Bonds in Molecular Crystals with Periodic Local Vibrational Mode Theory. Molecules 2020, 25, 1589. [CrossRef]

62. Grabowki, S. Tetrel bond- $\sigma$-hole bond as a preliminary stage of the $\mathrm{S}_{\mathrm{N}} 2$ reaction. Phys. Chem. Chem. Phys. 2014, 16, 1824-1834. [CrossRef] [PubMed]

63. Akiba, K.-Y.; Moriyama, Y.; Mizozoe, M.; Inohara, H.; Nishii, T.; Yamamoto, Y.; Minoura, M.; Hashizume, D.; Iwasaki, F.; Takagi, N.; et al. Synthesis and Characterization of Stable Hypervalent Carbon Compounds (10-C-5) Bearing a 2,6-Bis(p-substituted phenyloxymethyl)benzene Ligand. J. Am. Chem. Soc. 2005, 127, 5893-5901. [CrossRef]

64. Akiba, K.-Y.; Yamashita, M.; Yamamoto, Y.; Nagase, S. Synthesis and Isolation of Stable Hypervalent Carbon Compound (10-C-5) Bearing a 1,8-Dimethoxyanthracene Ligand. J. Am. Chem. Soc. 1999, 121, 10644-10645. [CrossRef]

65. Karim, A.; Schulz, N.; Andersson, H.; Nekoueishahraki, B.; Carlsson, A.-C.C.; Sarabi, D.; Valkonen, A.; Rissanen, K.; Gräfenstein, J.; Keller, S.; et al. Carbon's Three-Center, Four-Electron Tetrel Bond, Treated Experimentally. J. Am. Chem. Soc. 2018, 140, 17571-17579. [CrossRef] [PubMed]

66. Kovalevsky, A.Y.; Shishkin, O.V.; Ponomarev, I.I. N,N'-(Pyridine-2,6-diyl)bis(naphthalenedicarboximide) trifluoroacetic acid monohydrate. Acta Cryst. 1999, C55, 1914-1915. [CrossRef]

67. Alcock, N.W.; Harrison, W.D.; Howes, C. Secondary bonding. Part 13. Aryl-tellurium(IV) and -iodine(III) acetates and trifluoroacetates. The crystal and molecular structures of bis-(p-methoxyphenyl)tellurium diacetate, $\mu$-oxo-bis[diphenyltrifluoroacetoxytellurium] hydrate, and [bis(trifluoroacetoxy)iodo]benzene. J. Chem. Soc. Dalton Trans. 1984, 8, 1709-1716. [CrossRef]

68. Erben, F.; Vedova, C.O.D.; Willner, H.; Trautner, F.; Oberhammer, H.; Boese, R. Fluoroformyl Trifluoroacetyl Disulfide, FC(O)SSC(O)CF 3: Synthesis, Structure in Solid and Gaseous States, and Conformational Properties. Inorg. Chem. 2005, 44, 7070. [CrossRef] 
69. Minkwitz, R.; Berkei, M.; Ludwig, R. Synthesis and Characterization of Novel Iodine(III) Compounds; Crystal Structures of Methoxy(trifluoromethyl)iodine(III) Chloride [CF3I(Cl)OCH3] and Dimethoxy(trifluoromethyl)iodine(III) [CF3I(OCH3)2]. Eur. J. Inorg. Chem. 2000, 2387. [CrossRef]

70. Heywood, V.L.; Alford, T.P.J.; Roeleveld, J.J.; Deprez, S.J.L.; Verhoofstad, A.M.; van der Vlugt, J.I.; Domingos, S.R.; Schnell, M.; Davis, A.P.; Mooibroek, T.J. Observations of tetrel bonding between $\mathrm{sp}^{3}$-carbon and THF. Chem. Sci. 2020, 11, 5289-5293. [CrossRef]

71. Roeleveld, J.J.; Lekanne Deprez, S.J.; Verhoofstad, A.; Frontera, A.; van der Vlugt, J.I.; Mooibroek, T.J. Engineering Crystals Using sp ${ }^{3}-C$ Centred Tetrel Bonding Interactions. Chem Eur. J. 2020, 26, 10126-10132. [CrossRef]

72. Bauzá, A.; Mooibroek, T.J.; Frontera, A. Small Cycloalkane $(\mathrm{CN})_{2} \mathrm{C}-\mathrm{C}(\mathrm{CN})_{2}$ Structures Are Highly Directional Non-covalent Carbon-Bond Donors. Chem. Eur. J. 2014, 20, 10245-10248. [CrossRef] [PubMed]

73. Daolio, A.; Scilabra, P.; Terraneo, G.; Resnati, G. C $\left(\mathrm{sp}^{3}\right)$ atoms as tetrel bond donors: A crystallographic survey. Coord. Chem. Rev. 2020, 413, 213265. [CrossRef]

74. Witt, J.R.; Britton, D.; Mahon, C. The crystal structures of $\mathrm{BrC}(\mathrm{CN})_{3}, \mathrm{ClC}(\mathrm{CN})_{3}$, and $\mathrm{CH} 3 \mathrm{C}(\mathrm{CN})_{3}$. Acta Cryst. 1972, B28, 950. [CrossRef]

75. Franconetti, A.; Quiñonero, D.; Frontera, A.; Resnati, G. Unexpected chalcogen bonds in tetravalent sulfur compounds. Unexpected chalcogen bonds in tetravalent sulfur compounds. Phys. Chem. Chem. Phys. 2019, 21, 11313-11319. [CrossRef]

76. Britton, D. The crystal structure of tetracyanomethane, $\mathrm{C}(\mathrm{CN})_{4}$. Acta Cryst. 1974, B30, 1818-1821. [CrossRef]

77. Taheriha, M.; Ghadermazi, M.; Amani, V. Dimeric and polymeric mercury(II) complexes of 1-methyl-1,2,3,4-tetrazole-5-thiol: Synthesis, crystal structure, spectroscopic characterization, and thermal analyses. J. Mol. Struct. 2016, 1107, 57-65. [CrossRef]

78. Xu, X.; Ju, W.; Hou, W.; Zhu, D.; Xu, Y. Two octamolybdate-based complexes: Hydrothermal synthesis, structural characterization and properties. CrystEngComm 2014, 16, 82-88. [CrossRef]

79. Lyakhov, A.S.; Voitekhovich, S.V.; Ivashkevich, L.S.; Gaponik, P.N. 5-Amino-1-methyl-4H-tetra zolium picrate. Acta Cryst. 2005, E61, o3645-o3647. [CrossRef]

80. Pal, P.; Konar, S.; Lama, P.; Das, K.; Bauzá, A.; Frontera, A.; Mukhopadhyay, S. On the Importance of Noncovalent Carbon-Bonding Interactions in the Stabilization of a 1D Co(II) Polymeric Chain as a Precursor of a Novel 2D Coordination Polymer. J. Phys. Chem. B 2016, 120, 6803-6811. [CrossRef]

81. Morgunov, R.B.; Mushenok, F.B.; Aldoshin, S.M.; Sanina, N.A.; Yureva, E.A.; Shilov, G.V.; Tkachev, V.V. Thermally-induced paramagnetism of spiropyrane iodides. New J. Chem. 2009, 33, 1374-1379. [CrossRef]

82. Peter, A.; Fehr, S.M.; Dybbert, V.; Himmel, D.; Lindner, I.; Jacob, E.; Ouda, M.; Schaadt, A.; White, R.J.; Scherer, H.; et al. Towards a Sustainable Synthesis of Oxymethylene Dimethyl Ether by Homogeneous Catalysis and Uptake of Molecular Formaldehyde. Angew. Chem. Int. Ed. 2018, 57, 9461-9464. [CrossRef]

83. Finze, M.; Reiss, G.J. Trimethyl sulfonium 1-amino-6-fluoro-2,3,4,5,7,8,9,10,11,12-decaiodo-1-carba-closo-dodeca borate. Acta Cryst. 2012, E68, o640. [CrossRef]

84. Abramov, P.A.; Zakharchuk, N.F.; Virovets, A.V.; Mirzaeva, I.V.; Sokolov, M.N. Hydrogen selenide in M-Se and $\mathrm{C}-\mathrm{Se}$ bond formation. $\left[\mathrm{CP}_{3}{ }_{3} \mathrm{Ir}_{3} \mathrm{Se}_{2}\right]^{2+}$ clusters: New synthesis, molecular and electronic structure and related studies. J. Organomet. Chem. 2014, 767, 65-71. [CrossRef]

85. Arunan, E.; Desiraju, G.R.; Klein, R.A.; Sadlej, J.; Scheiner, S.; Alkorta, I.; Clary, D.C.; Crabtree, R.H.; Dannenberg, J.J.; Hobza, P.; et al. Definition of the hydrogen bond (IUPAC Recommendations 2011). Pure Appl. Chem. 2011, 83, 1637-1641. [CrossRef]

86. Lopez-Andarias, J.; Bauza, A.; Sakai, N.; Frontera, A.; Matile, S. Remote Control of Anion- $\pi$ Catalysis on Fullerene-Centered Catalytic Triads. Angew. Chem. Int. Ed. 2018, 57, 10883-10887. [CrossRef] [PubMed]

87. Lopez-Andarias, J.; Frontera, A.; Matile, S. Anion- $\pi$ Catalysis on Fullerenes. J. Am. Chem. Soc. 2017, 139, 13296-13299. [CrossRef]

88. Bornhof, A.-B.; Vázquez-Nakagawa, M.; Rodríguez-Pérez, L.; Herranz, M.A.; Sakai, N.; Martín, N.; Matile, S.; López-Andarias, J. Anion- $\pi$ Catalysis on Carbon Nanotubes. Angew. Chem. Int. Ed. 2019, 58, 16097-16100. [CrossRef]

(C) 2020 by the author. Licensee MDPI, Basel, Switzerland. This article is an open access article distributed under the terms and conditions of the Creative Commons Attribution (CC BY) license (http://creativecommons.org/licenses/by/4.0/). 